\title{
First megafossil evidence of Cyatheaceous tree fern from the Indian Cenozoic
}

\author{
Subir Bera $^{1, *}$, Sudha Gupta ${ }^{2}$, Mahasin Ali Khan $^{1}$, Aniruddha De ${ }^{1}$ \\ and Radhanath MukHopadhyaY ${ }^{3}$ \\ ${ }^{1}$ Centre of Advanced Study, Department of Botany, University of Calcutta, 35, B.C. Road, \\ Kolkata 700 019, West Bengal, India. \\ ${ }^{2}$ Department of Botany, University of Kalayni, Nadia 741 235, West Bengal, India. \\ ${ }^{3}$ Department of Botany, University of Burdwan, Burdwan 713 104, West Bengal, India. \\ ${ }^{*}$ Corresponding author.e-mail: berasubir@yahoo.co.in
}

A part of the compressed tree fern axis with leaf and adventitious root scars in unusual arrangement from Plio-Pleistocene sediments of Arunachal Pradesh, India is described as Cyathea siwalika sp. nov. This record suggests that Cyathea was an important component of tropical evergreen forest in the area during the Plio-Pleistocene and this group subsequently declined in importance within the local vegetation.

\section{Introduction}

Miocene to Pleistocene strata deposited as a piedmont along the southern flank of the Himalayas are rich in fossil plants but pteridophytes are rare and poorly preserved. Although dispersed spores of various fern groups have been recorded regularly, a few macroscopic fern remains have been reported. They were recorded from Uttarakhand, Assam and Arunachal Pradesh belonging to the Thelypteridaceae (Prasad 1991; Guleria and Srivastava 2000; Joshi and Mehrotra 2003; Prasad et al. 2004; Khan et al. 2007; Mehrotra et al. 2011). The entire Siwalik sedimentary succession has been assigned into three units such as lower part of the Siwalik (middle-upper Miocene), middle part of the Siwalik (Pliocene) and upper part of the Siwalik (upper Pliocene-lower Pleistocene) (Kumar 1997). Recently, on the basis of magnetostratigraphic data, Chirouze et al. (2012) proposed that the Siwalik Group in Arunachal Pradesh was deposited between 13 and 2.5 Ma. The transition between the lower and middle Siwaliks is dated at about
10.5 $\mathrm{Ma}$ and the middle to upper Siwaliks transition is dated at 2.6 Ma. The generalized NeogeneQuaternary stratigraphy of Arunachal Pradesh is given in table 1.

Here we describe the first evidence of Cyatheaceae based on a part of the compressed stem with leaf and adventitious root scars from the upper Siwalik of Papumpare district of Arunachal Pradesh, India (figure 1). This also appears to be the first macroscopic record of a cyatheaceous fern from the Indian Cenozoic.

\section{Material and methods}

The single available specimen is a carbonized (compressed) stem fragment with the scar of a petiole base surrounded by adventitious root scars. It was collected from the Kimin Formation (equivalent to the upper Siwalik: upper Pliocene-lower Pleistocene) of Papumpare district, Arunachal Pradesh (situated between $26^{\circ} 27^{\prime} 52^{\prime \prime}$ and $29^{\circ} 29^{\prime} 54^{\prime \prime} \mathrm{N}$ and $91^{\circ} 29^{\prime} 50^{\prime \prime}$ and $97^{\circ} 24^{\prime} 56^{\prime \prime} \mathrm{E}$ ), eastern Himalaya

Keywords. Cyathea siwalika; fern axis; leaf and root scars; Plio-Pleistocene; Arunachal Pradesh. 
Table 1. Neogene-Quaternary stratigraphy of Arunachal Pradesh (Kumar 1997).

\begin{tabular}{|c|c|c|c|c|c|}
\hline Period & Epoch & & Sub-Himalaya & Naga-Patkoi ranges & Brahmaputra plains \\
\hline \multirow{7}{*}{$\begin{array}{l}\text { Q } \\
u \\
a \\
\text { t } \\
\text { e } \\
\text { r } \\
\text { n } \\
\text { a } \\
\text { r } \\
y\end{array}$} & Holocene & & \multirow{3}{*}{ Newer Alluvium } & \multirow{3}{*}{ Newer Alluvium } & \multirow{3}{*}{ Newer Alluvium } \\
\hline & & & & & \\
\hline & \multirow{5}{*}{ Pleistocene } & $\mathrm{U}$ & & & \\
\hline & & $\mathrm{M}$ & Older Alluvium (Hapoli Fm.) & Older Alluvium & Older Alluvium \\
\hline & & $\mathrm{L}$ & \multirow{4}{*}{ Kimin Fm. (Upper Siwalik) } & \multirow{4}{*}{ Dihing Fm. } & \multirow{4}{*}{ Dhekiajuli Fm. } \\
\hline & & & & & \\
\hline & & & & & \\
\hline \multirow{5}{*}{$\begin{array}{l}\mathrm{N} \\
\mathrm{e} \\
\mathrm{o} \\
\mathrm{g} \\
\mathrm{e} \\
\mathrm{n} \\
\mathrm{e}\end{array}$} & \multirow[b]{2}{*}{ Pliocene } & $\mathrm{U}$ & & & \\
\hline & & $\mathrm{L}$ & Subansiri Fm. (Middle Siwalik) & Namsang Fm. & $\begin{array}{l}\text { Namsang Fm./ } \\
\text { Dupi Tila Fm. }\end{array}$ \\
\hline & \multirow{3}{*}{ Miocene } & $\mathrm{U}$ & Dafla Fm. (Lower Siwalik) & Girujan Fm. & Girujan Fm. \\
\hline & & $\mathrm{M}$ & Kimi Fm. & Tipam Fm. & Tipam Fm. \\
\hline & & $\mathrm{L}$ & Tourmaline granite & Surma Group? & Surma Group \\
\hline
\end{tabular}

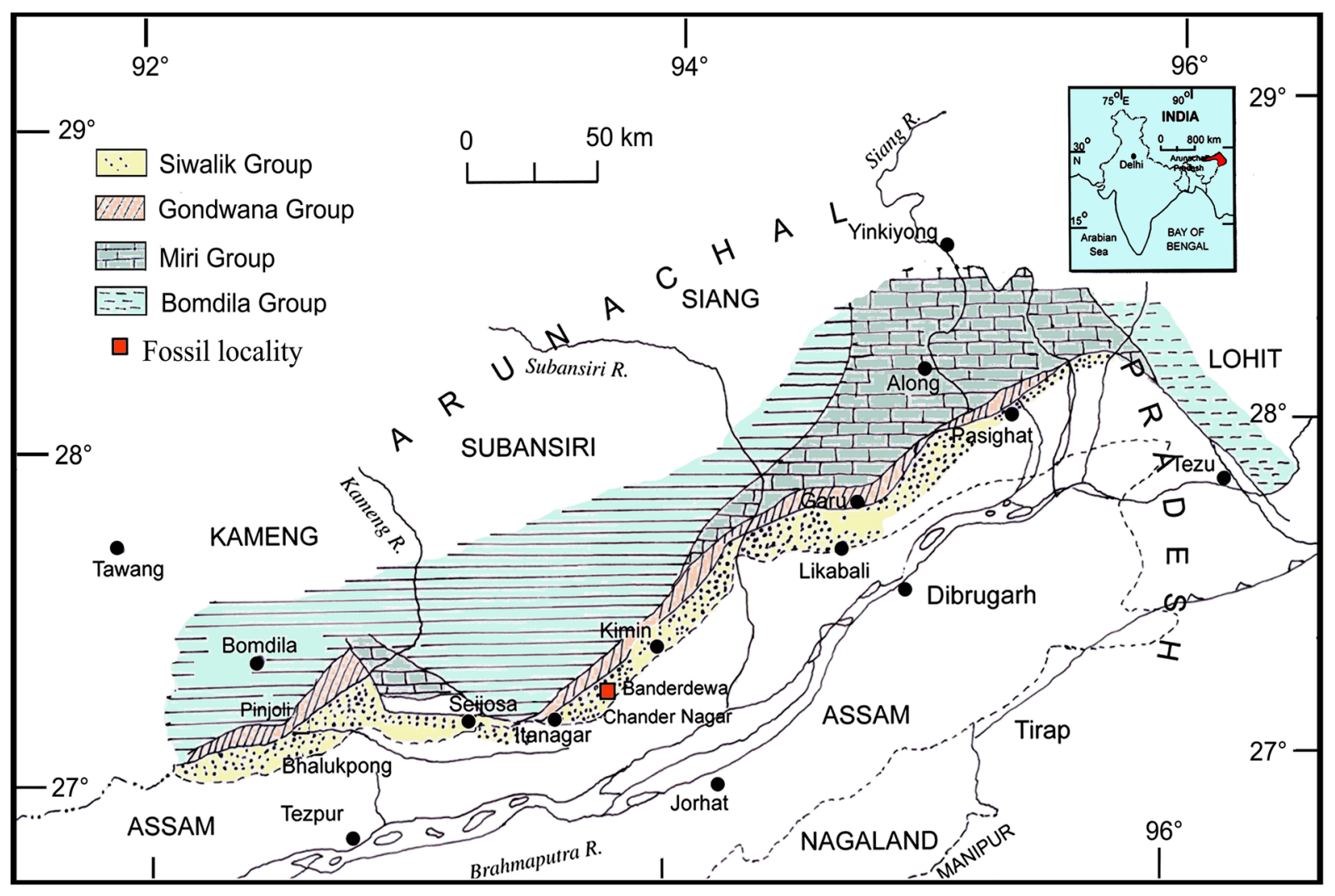

Figure 1. Geological map of Arunachal foothill (modified after Singh and Tripathi 1990), red square indicates the fossil locality.

(figure 1). This formation is characterized by alternation of loosely packed, very coarse-to-fine grained, friable, grey sandstones, silt, clay and gravelly-boulder beds (Kumar 1997). External morphology of the fossil remains was studied with a hand lens and incident light microscopy. Photographs showing structural details of the fossil specimen were taken using an incident light compound microscope (Stemi SV 11, Zeiss). The format of the descriptions and author citation of a new plant fossil species is mainly after Punt (1994). Holotype specimen is housed in the Herbarium and Museum of the Department of Botany, University of Calcutta (CUH), Kolkata. 


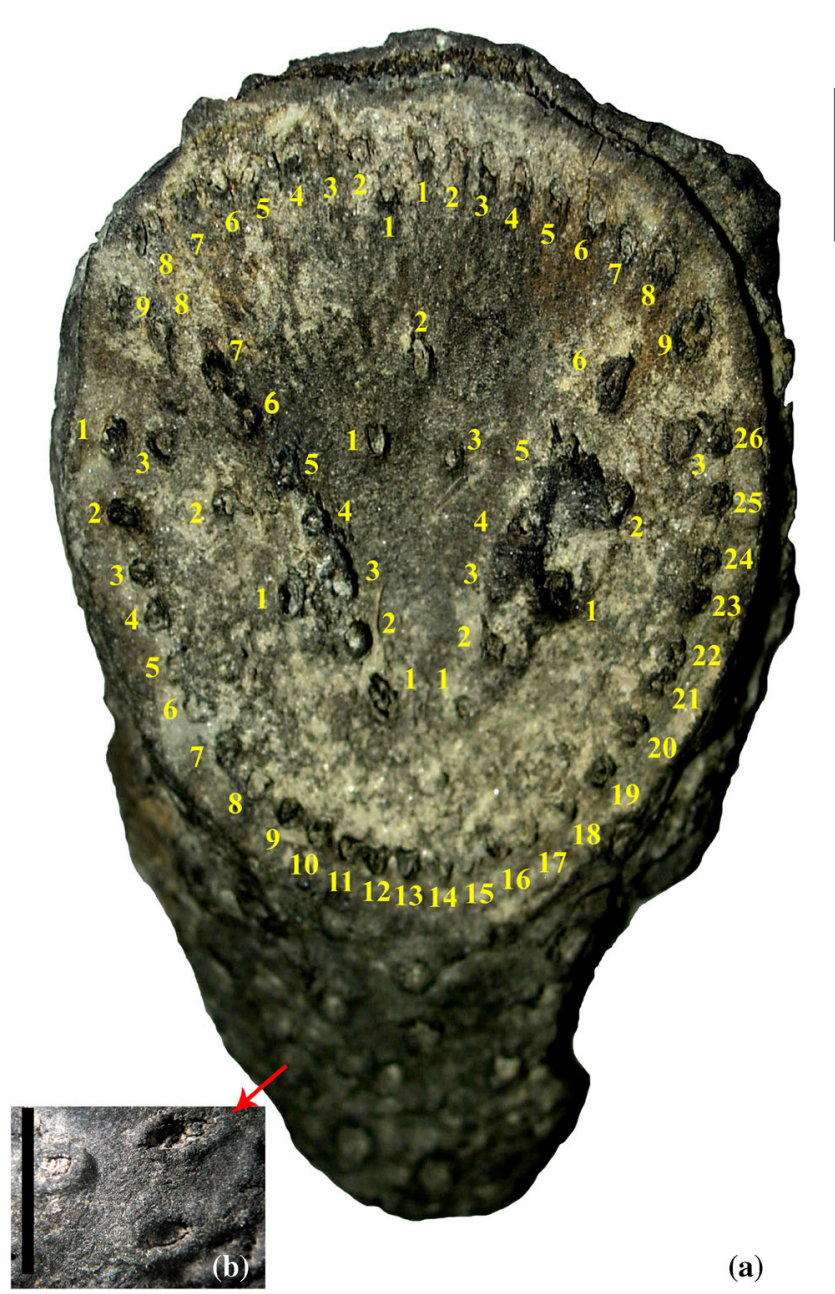

Figure 2. Cyathea siwalika Bera, Gupta et Mukhopadhyay sp. nov. CUH/PPL/IB7/TF/1. (a) Cyatheoid arrangemement of vascular bundles within the leaf scar. Scale bar = $1 \mathrm{~cm}$. (b) Stem surface showing the marks of root traces within root (marked by red arrow). Scale bar $=0.5 \mathrm{~cm}$.

\section{Systematic description}

Order: Cyatheales

Family: Cyatheaceae Kaulfuss

Genus: Cyathea Smith

Species: Cyathea siwalika Bera, Gupta et Mukhopadhyay, sp. nov. (figures 2 and 3)

Diagnosis: Stem fragment associated with an obovate leaf scar, ca. $8 \mathrm{~cm}$ long, $4.5 \mathrm{~cm}$ wide; surface with scars of adventitious roots. Leaf traces in Cyathea-type arrangement; three meristeles of median pair remain free. Adaxial arc consists of nine pairs of bundles; the superior series of lateral folds of 6-8 pairs of bundles, the inferior one of three pairs, and the abaxial arc 26. Vascular formula (Nishida 1981b) is - (8x4.5): 3i-9-6(8)-3-26.

Description: The specimen consists of a stem fragment associated with a single well-preserved leaf scar that consists of a surface ornamented by numerous adventitious root scars (figure 2a). The leaf scar is obovate, ca. $8 \mathrm{~cm}$ long, $4.5 \mathrm{~cm}$ wide, and is enclosed by strongly developed fundamental tissue of the leaf cushion. The vascular system supplying the leaf comprises numerous meristeles arranged in 'Cyathea type' (Ogura 1972), two '7'shaped as the adaxial or upper strand and one arc shaped as the abaxial or lower strand with more or less incurved margins. Individual meristeles are small, 'V'-shaped and 1-1.5 mm in diameter. Three meristeles that are comparable with the median pair bundles (Nishida 1981b) remain isolated in the middle part of the petiole base. The adaxial arc consists of 9 pairs of bundles. The superior series of lateral fold is composed of 6-8 pairs of bundles, the inferior one of three pairs. The lower or abaxial arc is composed of 26 bundles (figure 2a). Both medullary and cortical meristeles, are evident on the inner (axial) side of the specimen (figure $3 \mathrm{~b}$ ). Vascular formula is $(8 \times 4.5)$ : 3i-9-6(8)-3-26 (letter 'i' meaning isolated, after the total number of the median pair traces). The narrow basal portion of preserved stem surface is clothed with adventitious root scars (figure $2 \mathrm{~b}$ ) that are $2-4 \mathrm{~mm}$ in diameter.

Holotype: Specimen no. CUH/PPL/IB7/TF/1.

Horizon: Kimin Formation.

Locality: Road cuts along the Itanagar-Bandardewa road in Papumpare District.

Age: Late Pliocene to Early Pleistocene.

Material: One well-preserved specimen.

Etymology: Species named after Siwalik Group.

Affinities: The vascular traces arranged in a cyathean pattern of Ogura's leaf base suggest that the specimen shows closest affinity with the family Cyatheaceae, especially with the genus Cyathea Smith (sensu Kramer 1990). The family Cyatheaceae was composed of the genera Lophosoria, Metaxya, Thyrsopteris, Dicksonia, Cystodium, Cibotium, Culcita, Cyathea and Cnemidaria (Mettenius 1856). Bower (1926) however, gave much importance to the soral positions and created two families, Cyatheaceae and Dicksoniaceae, widely separated from each other. He included Dennstaedtia and other related genera in the Dicksoniaceae. Holttum and Sen (1961) considered that such wide separation between the Cyatheaceae and Dicksoniaceae was unwarranted since the early developmental stages of their sori were closely similar. They admitted that a degree of relationship exists between the dennstaedtioids and cyatheoids but preferred to exclude the dennstaetioids from the Cyatheaceae. However, this idea did not gain much acceptance (Kramer 1990). Existing molecular evidence indicate a close relationship among the families Cyatheaceae, Thyrsopteridaceae, Loxomataceae, Culcitaceae, Plagiogyriaceae, Cibotiaceae, Dicksoniaceae and Metaxyaceae (Hasebe 

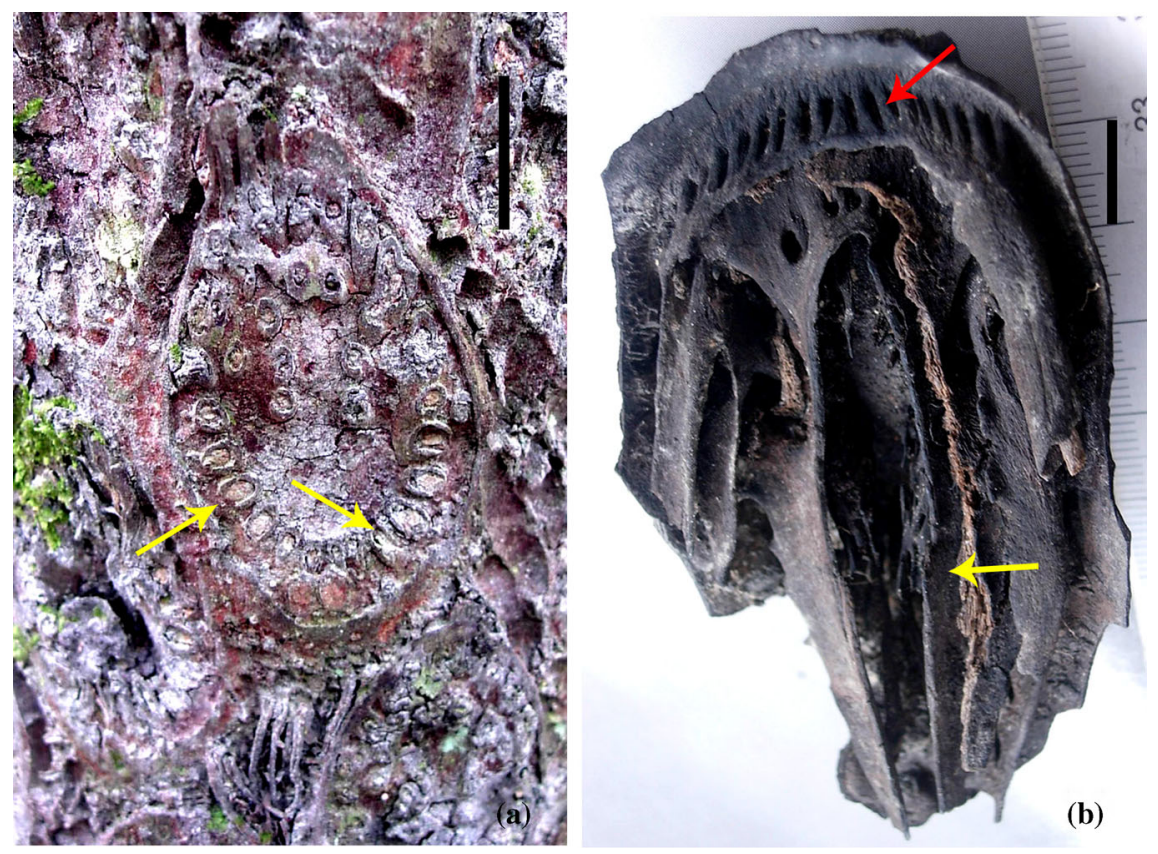

Figure 3. (a) An extant species of Cyathea Smith showing oval-leaf scars with more or less similar vascular arrangement (marked by yellow arrows). (b) An interior view of the leaf scar (from the cortical side) of the fossil leaf scar of $C$. siwalika Bera, Gupta et Mukhopadhyay sp. nov., showing medullary meristele (marked by yellow arrow) and cortical meristeles (marked by red arrow). Scale bar $=1 \mathrm{~cm}$.

et al. 1995; Wolf et al. 1999; Pryer et al. 2004; Smith et al. 2006). There are some anatomical studies on tree-fern stipes and stems (Thomae 1886; Ogura 1972; Nishida 1984). We are unable to trace its affinity with any known extant species of Cyathea on the basis of only vascular traces (figure 3a). Although the present specimen is morphologically only partly preserved showing a part of stem with vascular traces of leaf and adventitious roots, no fossil cyatheaceous fern is recorded so far with these combinations of characters and therefore a new species, Cyathea siwalika, is proposed for the fossil fern specimen.

\section{Discussion}

Cyathea Smith (Cyatheaceae sensu Kramer 1990) represents tree ferns ranging in age from the Jurassic to present (Taylor et al. 2009). Several structurally preserved stems of Cyatheaceae are found as fossil records. Ogura (1927) described a Cretaceous fern Cyathocaulis naktongensis from Korea and Japan having resemblance with the stem anatomy of extant Cyathea. Later, Ogura (1941a, b) described a number of taxa, viz., Cyathocaulis tateiwai, C. yabei from the early Cretaceous of Korea and Philippines, and Cibotium iwatense from the late Cretaceous of Japan. Other Cretaceous genera with cyatheaceous affinity are Cauloperis brownii from England (Renault 1883), Yezopteris polycycloides, Cyathocaulis yezopteroides, Cibotiocaulis from Japan, Saghalien, and Korea (Nishida 1981a, 1989), Oguracaulis banksii from Tasmania (Tidwell et al. 1989), Conantiopteris schuchmanii from California (Lantz et al. 1999) and Rickwoodopteris hirsuta from western North America (Stockey and Rothwell 2004).

Cyathorachis is a Cretaceous genus used for rachides comparable with extant Cyatheaceous members (Nishida 1981b). There are a few reports of Cyatheaceous pinnules with sori (Collinson 2001; Skog 2001). Smith et al. (2003) described Cyathea cranhamii, an anatomically preserved tree fern sori from the early Cretaceous of Vancouver Island, British Columbia. Recently, Vera (2013) described a new cyathealean tree fern, Yavanna chimaerica from the early Cretaceous of Livingston Island, Antarctica.

Cenozoic records of Cyatheaceous members are Dendropteridium cyatheoides from the late Tertiary of Kenya (Bancroft 1932), Cyathodendron texanum from the late Eocene of Texas (Arnold 1945), Alsophilocaulis calveoli from the Tertiary of Argentina (Menendez 1961), Cibotium tasmanense from the Tertiary of Tasmania (Gould 1972), Cibotium oregonense from the late Eocene of Oregon, western North America (Barrington and Davis 1983) and Nishidacaulis burgii from EoceneOligocene of Nebraska, South Dakota, USA (Tidwell and Nishida 1993).

In the Indian Cenozoic, Cyatheaceae are known only on the basis of dispersed spores (viz., various representatives of Cyathidites: see Saxena and Trivedi 2006), macroscopic remains have not been recovered to date. Both Cyathidites major Kar 
et al. (1994) and C. minor Couper. Kar (1990) have been recovered from the sediments hosting Cyathea siwalika (Khan et al. 2006; Paruya 2012).

The extant species of Cyathea (sensu Kramer 1990) grow in habitats ranging from tropical rain forests to temperate woodlands in pantropical to southern temperate regions of the world (Kramer 1990; Braggins and Large 2004). They are prevalent from lowland to montane as well as subalpine vegetation. Some species occur in the understorey of moist forests and in ravines, others prefer more open habitats, even swamps, while some grow preferentially in disturbed sites as an important constituent of pioneer vegetation (Kramer 1990). Cyathea is a significant component of tropical forests of southern, central, northern and eastern India (Dixit 1984). Among the 11 species of Cyathea in India, Cyathea spinulosa Wall. and Cyathea contaminans (Hook) Copel. are widely distributed through the mountainous regions. In Arunachal Himalaya, the genus is restricted to the tropical evergreen forest zone (up to $1000 \mathrm{~m}$ ), whereas the study area lies within the tropical semi-evergreen forest zone (up to $600 \mathrm{~m}$ ) where Cyathea is rare (Hazra et al. 1996).

Earlier recorded mega plant fossil (Joshi et al. 2003a, b; Bera et al. 2004; Joshi and Mehrotra 2007; Bera and Khan 2009; Khan et al. 2011, 2014 and Khan and Bera 2014a, b) and palynofossil (Khan et al. 2006) data clearly suggests that tropical evergreen forest cover was prevailing in the study area under a tropical warm humid climate during the Siwalik sedimentation period (late Pliocene to early Pleistocene). Therefore, present record suggests that Cyathea was an important component of tropical evergreen forest cover in the area during the Plio-Pleistocene. Later, the forest was slightly changed to tropical semi-evergreen type due to eco-climatic changes owing to the possible upheaval of the Himalayas and perhaps this is the reason for the rare occurrence of modern Cyathea in the tropical semi-evergreen forest zone of Arunachal Pradesh.

\section{Acknowledgements}

Department of Science and Technology, New Delhi is acknowledged for financial assistance. Authors are thankful to Sri Bimalendu De, Ex Dy. D.G. and Sri Sambhu Chakrabarty, Sr. Geologist, Geological Survey of India, Operation Arunachal, Itanagar for the help and co-operation during collection of fossil specimens.

\section{References}

Arnold C A 1945 Silicified plant remains from the Mesozoic and Tertiary of western North America. Part I: Ferns; Paper Mich. Acad. Sci. Lett. Arts 30 3-34.
Bancroft H 1932 A fossil cyatheoid stem from Mt. Elgon, East Africa; New Phytologist 31(4) 241-253.

Barrington D S and Davis S 1983 Cibotium oregonense: An Eocene tree fern stem and petioles with internal structure; Amer. J. Bot. 70(8) 1118-1124.

Bera S, De A and De B 2004 First record of Elaeocarpus Linn. Fruits from the upper Siwalik sediments (Kimin Formation) of Arunachal Pradesh, India; J. Geol. Soc. India 64 350-352.

Bera S and Khan M 2009 Record of fruit and leaflet cf. Pongamia pinnata (L.) Pierre from the upper Siwalik sediments (Kimin Formation) of Arunachal Pradesh; In: Advances in Plant Biology (Debasis Bhattacharya Birth Centenary Commemorative volume) (eds) Mondal S and Bhattacharya S, pp. 432-441.

Bower F O 1926 The Ferns (Filicales); Vol. II, Cambridge University Press, New York, 360p.

Braggins John E and Large M F 2004 Tree Ferns; Timber Press Inc., ISBN 0-88192-630-2.

Chirouze F, Dupont-Nivet G, Huyghe P, van der Beek P, Chakraborti T, Bernet M and Erens V 2012 Magnetostratigraphy of the Neogene Siwalik Group in the far eastern Himalaya: Kameng section, Arunachal Pradesh, India; J. Asian Earth Sci. 44 117-135.

Collinson M E 2001 Cainozoic ferns and their distribution; Brittonia 53 173-235.

Dixit R D 1984 A census of the Indian Pteridophytes; Botanical Survey of India, Howrah, 177p.

Gould R E 1972 Cibotium tasmanense sp. nov. a fossil tree fern from the Tertiary of Tasmania; Aust. J. Botany 20 119-126.

Guleria J S and Srivastava R 2000 Observation on the fossil fern Goniopteris prolifera Presl and its present status; Phytomorphology 50 11-13.

Hasebe M, Wolf P G, Pryer K M, Ueda K, Ito M, Sano R, Gastony J G, Yokoyama J, Manhart J R, Murakami N, Crane E H, Haufler C H and Hauk W D 1995 Fern phylogeny based on rbcL nucleotide sequences; Amer. Fern J. 85 134-181.

Hazra P K, Verma D M and Giri G S (eds) 1996 Materials for the Flora of Arunachal Pradesh; Bot. Surv. India, Govt. of India; pp. 1-693.

Holttum R E and Sen U 1961 Morphology and the classification of the tree ferns; Phytomorphology 11(4) 406420 .

Joshi A and Mehrotra R C 2003 A Thelypteridaceous fossil fern from the Lower Siwalik of the east Kameng district, Arunachal Pradesh, India; J. Geol. Soc. India 61(4) 483-486.

Joshi A and Mehrotra R C 2007 Megaremains from the Siwalik sediments of west and east Kameng Districts, Arunachal Pradesh; J. Geol. Soc. India 69 1256-1266.

Joshi A, Tewari R, Mehrotra R C, Chakraborty P P and De A 2003a Plant remains from the Upper Siwalik sediments of west Kameng District, Arunachal Pradesh; J. Geol. Soc. India 61(3) 319-324.

Joshi A, Mehrotra R C and De A 2003b A fossil wood from the Upper Siwalik sediments of west Kameng district, Arunachal Pradesh, India; Proceedings of GEOSAS-IV, pp. 312-315.

Kar R K 1990 Palynology of Miocene and Mio-Pliocene sediments of north-east India; J. Palynol. 26 171-217.

Kar R K, Handique G K, Kalita C K, Mandal J, Sarkar S, Kumar M and Gupta A 1994 Palynostratigraphical studies on subsurface Tertiary sediments in Upper Assam Basin, India; Palaeobotanist 42(2) 183-198.

Khan M A, Gupta S, Parua D, De A, De B and Bera S 2006 Palynoassemblage from Upper Siwalik sediments of Papumpare district, Arunachal Pradesh with remarks on palaeoenvironment; J. Bot. Soc. Bengal 60(1) 44-49. 
Khan M A, De B and Bera S 2007 A fossil fern-leaflet of family Thelypteridaceae from the Middle Siwalik sediments of west Kameng district, Arunachal Pradesh; J. Bot. Soc. Bengal 61(1) 65-69.

Khan M A and Bera S 2014a On some fabaceous fruits from the Siwalik sediments (Middle Miocene-Lower Pleistocene) of eastern Himalaya; J. Geol. Soc. India $\mathbf{8 3}$ $165-174$.

Khan M A and Bera S 2014b New lauraceous species from the Siwalik forest of Arunachal Pradesh, eastern Himalaya, and their palaeoclimatic and palaeogeographic implications; Turk. J. Bot. 38 453-464.

Khan M A, Ghosh R, Bera S, Spicer R A and Spicer T E V 2011 Floral diversity during Plio-Pleistocene Siwalik sedimentation (Kimin Formation) in Arunachal Pradesh, India, and its palaeoclimatic significance; Palaeobiodiversity and Palaeoenvironment 91 237-255.

Khan M A, Spicer R A, Bera S, Ghosh R, Yang J, Spicer T E V, Guo S, Su T, Jacques F and Grote P J 2014 Miocene to Pleistocene floras and climate of the eastern Himalayan Siwaliks, and new Palaeoelevation estimates for the Namling-Oiyug Basin, Tibet; Global Planet. Change 113 1-10.

Kramer K U 1990 Cyatheaceae: The familes and genera of vascular plants; vol. 1, Pteridophytes and gymnosperms (eds) Kramer K U and Green P S, Springer-Verlag, Berlin, Germany, pp. 69-74.

Kumar G 1997 Geology of Arunachal Pradesh; Geol. Soc. India, Bangalore, pp. 1-217.

Lantz T C, Rothwell G W and Stockey R A 1999 Conantiopteris schuchmanii gen. et. sp. nov. and the role of fossils in resolving the phylogeny of Cyatheaceae s.l.; $J$. Plant Res. 112 361-381.

Mehrotra R C, Basumatary S K, Bera S K, Srivastava G, Sarma G C and Baruah C K 2011 First report of the plant fossils from the Manas National Park, Assam, India; Palaeobotanist 60(2) 273-280.

Menendez C A 1961 Estipite petrificado de una nueva Cyatheceae del Terciario de Neuquen; Bol. Soc. Argentina Bot. 9 331-358.

Mettenius G 1856 Filices horti botanici Lipsiensis; Leipzig.

Nishida H 1981a Anatomical studies of a new specimen of Yezopteris polycycloides Ogura from the Upper Cretaceous of Hokkaido; J. Japan Bot. 56 169-180.

Nishida H 1981b A revision of the genus Cyathorachis in Japan; Bot. Mag. Tokyo 94 249-259.

Nishida H 1984 Anatomical studies of the frond axis of the Cyatheaceae, s.l. with a revision of permineralized frond axes from the Cretaceous of Japan; In: Contributions to the Botany in the Andes 1984 (ed.) M Nishida, 5-80, 76 pls.

Nishida H 1989 Structure and affinities of the petrified plants from the Cretaceous of Japan and Saghalien: V. Tree fern stems from Hokkaido, Paracyathocaulis ogurae gen. et. comb. nov. and Cyathocaulis yezopteoides sp. nov.; Bot. Mag. Tokyo 102 255-282.

Ogura Y 1927 On the structure and affinities of some fossil tree ferns from Japan; J. Fac. Sci. Imper. Univ. Tokyo Bot. Tokyo 1(3) 351-380.

Ogura Y 1941a On the structure of a fossil tree fern stem from Mindoro, Philippine Islands; Jubil. Publ. Prof. Yabe 911-917, $1 \mathrm{pl}$.

Ogura Y 1941b Additional notes on the structure of fossil tree ferns; Bot. Mag. Tokyo 55 453-461.
Ogura Y 1972 Comparative anatomy of vegetative organs of the pteridophytes; Gebruder Borntraeger, 502p.

Paruya D K 2012 Neogene Quaternary palynostratigraphy of eastern Himalaya with reference to palaeoenvironment and palaeogeography, Ph.D. thesis, University of Calcutta, Calcutta.

Prasad M 1991 Fossil fern Goniopteris prolifera Presl from the Siwalik sediments near Nainital, North India; Curr. Sci. 60 655-656.

Prasad M, Ghosh R and Tripathi P P 2004 Floristics and climate during Siwalik (Middle Miocene) near Kathgodam in the Himalayan foothills of Uttaranchal, India; J. Palaeontol. Soc. India 49 35-93.

Pryer K M, Schuettpelz E, Wolf P G, Schneider H, Smith A R and Cranfill R 2004 Phylogeny and evolution of ferns (monilophytes) with a focus on the early leptosporangiate divergences; Am. J. Bot. 91 1592-1598.

Punt W 1994 Format of descriptions of new taxa of fossil plants (genera, species); Rev. Palaeobot. Palynol. 80 7-8.

Renault M B 1883 Cours de Botanique Fossile; 3. L'Acad. de Med. Paris.

Saxena R K and Trivedi G K 2006 A catalogue of Tertiary spores and pollen from India; Diamond Jubilee Special Publication, Birbal Sahni Institute of Palaeobotany, Lucknow, pp. 36-37.

Singh T and Tripathi S K M 1990 Siwalik sediments of Arunachal Himalaya: Palynology, palaeoecology and palaeogeography; Palaeobotanist 38 325-332.

Skog J E 2001 Biogeography of Mesozoic leptosporangiate ferns related to extant ferns; Brittonia 53 236-269.

Smith S Y, Rothwell G W and Stockey R A 2003 Cyathea cranhamii sp. nov. (Cyatheaceae). Anatomically preserved tree fern sori from the Lower Cretaceous of Vancouver island, British Columbia; Amer. J. Bot. 90 755760.

Smith A R, Pryer K M, Schuettpelz E, Korall P, Schneider $\mathrm{H}$ and Wolf P G 2006 A classification for extant ferns; Taxon 55(3) 705-731.

Stockey R A and Rothwell G W 2004 Cretaceous tree ferns of western North America: Rickwoodopteris hirsuta gen. et. sp. nov. (Cyatheacceae s.l.); Rev. Palaeobot. Palynol. 132(1-2) 103-114.

Taylor T N, Taylor E L and Krings M 2009 The biology and evolution of fossil plant; Prentice Hall, 2nd edn, Elsevier Publication, pp. 529-739.

Thomae K 1886 Die Blattstiele der Ferne, Ein Beitrag zur vergleichenden Anatomie; Jahrb. Wiss. Bot. 17 99-161.

Tidwell W D and Nishida H 1993 A new fossilized tree fern stem, Nishidacaulis burgii gen. et sp. nov., from Eocene-Oligocene of Nebraska, South Dakota, USA; Rev. Palaeobot. Palynol. 78 55-67.

Tidwell W D, Nishida H and Webster N 1989 Oguracaulis banksii gen. et. sp. nov., a mid-Mesozoic tree fern stem from Tasmania, Australia; Papers Proc. Roy. Soc. Tasmania 123 15-25.

Vera E I 2013 New cyathealean tree fern, Yavanna chimaerica gen. et sp. nov., from the early Cretaceous of Livingston Island, Antarctica; Cretaceous Res. 44 214-222, http://dx.doi.org/10.1016/j.cretres.2013.04.011.

Wolf P G, Stipes S D, White M R, Martines M L, Pryer K M, Smith A R and Ueda K 1999 Phylogenetic relationships of the enigmatic fern families Hymenophyllopsidaceae and Lophosoriaceae: Evidence from rbcL sequences; Pl. Syst. Evol. 3 383-392. 